\title{
ABSTRAK
}

\section{PENDIDIKAN KESEHATAN MENGENAI PERUBAHAN YANG TERJADI PADA PEREMPUAN MENOPAUSE DAN PENGELOLAANNYA}

\author{
Wardani, Desy Ayu' ${ }^{1}$, Mukaromah, Siti $^{2}$ \\ Program Studi Ilmu Keperawatan, Institut Teknologi Kesehatan dan Sains Wiyata Husada Samarinda ${ }^{1,2}$ \\ Korespondensi: desyayuwardani@stikeswhs.ac.id, sitimukaromah@itkeswhs.ac.id
}

\begin{abstract}
Menopause adalah fase alamiah yang akan dialami oleh setiap wanita yang biasanya terjadi diantara usia 40 tahun, sekitar usia 40-45 tahun. Menopause merupakan kondisi akhir proses biologis yang menandai berakhirnya masa subur seorang wanita. Kondisi ini menstruasi telah berhenti dalam 1 tahun yang akan berdampak pada konsekuensi kesehatan baik fisik maupun psikis dan angka harapan hidup. Keluhan fisik dan psikologis dirasakan sekitar setahun atau dua tahun setelah masa menstruasi. Keluhan fisik yang timbul diantaranya perasaan panas (hot flushes), keringat berlebihan pada malam hari, insomnia, kekeringan pada vagina, sakit dan nyeri pada persendian, berat badan bertambah. Keluhan psikis diantaranya cemas, emosi yang labil, daya ingat menurun, sulit berkonsentrasi, sulit mengambil keputusan dan merasa tidak berharga. Kegiatan Pendidikan kesehatan (penyuluhan) kesehatan mengenai perubahan - perubahan yang terjadi selama masa menopause dan cara pengelolaannya ini ditujukan pada perempuan dewasa akhir dan perempuan yang sudah menopause RT 41 Kelurahan Loa Bahu Kecamatan Sungai Kunjang Kota Samarinda. Sebanyak kurang lebih 25 peserta yang terlibat dalam kegiatan ini. Hasil dari penilaian kuesioner menunjukkan bahwa nilai pengetahuan peserta terdapat perbedaan sebelum dan sesudah diberikan pendidikan kesehatan mengenai perubahan yang terjadi saat menopause dan pengelolaannya yang dibuktikan dengan terjadi peningkatan nilai pengetahuan pada hampir semua peserta.
\end{abstract}

Kata kunci: Edukasi Kesehatan, Perubahan dan pengelolaan, Menopause

\section{PENDAHULUAN}

Menopause merupakan suatu fase alamiah yang akan dialami oleh setiap wanita yang biasanya terjadi diantara usia 40 tahun, Sekitar usia 40-45 tahun. Kondisi ini merupakan suatuakhir proses biologis yang menandai berakhirnya masa subur seorang wanita. Dikatakan menopause bila siklus menstruasinya telah berhenti dalam 1 tahun. Berhentinya haid tersebut akan membawa dampak pada konsekuensi kesehatan baik fisik maupun psikis selain berdampak pada fisik dan psikis juga berdampak pada angka harapan hidup (Emilda, 2016).

Dampak masalah kesehatan pada usia perempuan menopause yang terjadi baik secara fisik dan psikologis. Salah satunya yaitu terjadi perubahan psikologis dimana perempuan merasa cemas dan takut ketika telah memasuki masa menopauase. Perubahan psikologis pada wanita menopause dapat berdampak pada keadaan sosial yang dirasakannya, keadaan sosial ekonomi yang memperngaruhi faktor fisik, kesehatan dan pendidikan. Keadaan sosial yang dirasakan adalah takut kehilangan fungsi dan ekstensi sebagai wanita, takut tidak bisa memuaskan atau melayani suami, takut kehilangan kasih sayang atau suami mencari wanita lain (Emilda, 2016).

Perubahan fisik dan psikologis yang terjadi pada perempuan menopause mengakibatkan timbulnya satu krisis dan dimanisfestasikan diri dalam keluhankeluhan fisik dan psikologis yang biasanya dirasakan sekitar setahun atau dua tahun setelah masa menstruasi terakhir.Keluhan fisik yang timbul adalah perasaan panas (hot flushes), keringat berlebihan pada malam hari, insomnia, kekeringan pada vagina, sakit dan nyeri pada persendian, berat badan bertambah.Sementara keluhan psikis adalah cemas, emosis yang labil, daya ingat menurun, sulit berkonsentrasi, sulit 
mengambil keputusan, dan merasa tidak berharga. Keluhan fisik maupun psikis ini tentu akan saja akan memperngaruhi kualitas hidupnya (Merkawati, 2013).Masalah psikologis yang dihadapi perempuan pada masa menopause adalah seperti mood, daya ingat dan depresi. Masalah psikologis dan fisik yang dialami perempuan pada menopause akan berkaitan dengan kualitas hidup seseorang.

Total populasi wanita yang mengalami menopause menurut WHO mencapai 373 juta orang di tahun 2012 dan diperkirakan akan mencapai 1,2 milyar orang pada tahun 2030. Badan Pusat Statistik (BPS) menyimpulkan bahwa jumlah penduduk wanita berusia di atas 50 tahun meningkat dari 10,7 juta menjadi 37,3 juta orang dan diperkirakan tahun 2025 akan menjadi 75 juta orang (Ulfah, 2017). Sensus penduduk di Indonesia tahun 2013 jumlah perempuan berusia diatas 50 tahun baru mencapai 15,5 juta jiwa dari total penduduk, sedangkan tahun 2020 jumlahnya diperkirakan meningkat menjadi 30,0 juta jiwa dari total penduduk (Depkes, 2013). Kondisi peningkatan usia harapan hidup, pada akhir tahun 2013 sasaran yang dicapai di Kalimantan Timur ialah dari 67,2 tahun menjadi 70,6 tahun. Pada tahun 2017 usia harapan hidup di Kalimantan Timur meningkat menjadi 73,1 tahun, dari peningkatan usia harapan hidup tersebut dapat dilihat bahwa adanya peningkatan kesejahteraan perempuan di Kalimantan Timur hingga mencapai tahap menopause (BPPD (2007), dalam Syukur, 2017).

\section{METODE PELAKSANAAN}

Adapun metode pelaksanaan dan alur pelaksanaan pengabdian masyarakat ini yaitu:

1. STIKES WHS bekerja sama dengan Ketua RT 41 kelurahan Loa Bahu
Kecamatan Sungai Kunjang untuk melaksanakan pengkajian kebutuhan promosi kesehatan.

2. Melakukan analisa hasil pengkajian dan memaparkan rencana program pendidikan kesehatan yang akan dilakukan tentang perubahan yang terjadi pada menopause dan pengelolaanya.

3. Bersama Ketua RT 41 dan pelaksana pengabdian masyarakat menetapkan tempat dan tanggal pelaksanaan.

4. Pelaksana menyiapkan media yang digunakan saat penyuluhan. Pelaksana menggunakan media leaflet dalam penyuluhan ini.

5. Pada tanggal 21 Desember 2018, pelaksana melakukan penyuluhan tentang perubahan yang terjadi pada menopause dan pengelolaanya.

6. Sebelum melakukan penyuluhan, pelaksana terlebih dahulu membagikan kuesioner mengenai perubahan yang terjadi pada menopause dan pengelolaanya.

7. Melakukan penyuluhan/ pendidikan kesehatan tentang menarche dengan menggunakan powerpoint dengan teknik ceramah.

8. Setelah selesai pendidikan kesehatan diberikan waktu untuk peserta bertanya.

9. Peserta diberikan kuesioner kembali untuk diisi.

10. Pelaksana mengumpulkan kuesioner sebelum dan sesudah diberikan pendidikan kesehatan.

11. Pelaksana menyimpulkan hasil pendidikan kesehatan kepada peserta.

\section{HASIL}

Pelaksana melakukan evaluasi dalam bentuk penilaian kuesioner yang sudah diisi oleh peserta sebelum dan sesudah diberikan penyuluhan/pendidikan kesehatan mengenai 
perubahan yang terjadi saat menopause dan pengelolaannya. Jumlah pernyataan dalam kuesioner sejumlah 20 pertanyaan. Adapun hasil dari penilaian kuesioner menunjukkan bahwa nilai pengetahuan peserta terdapat perbedaan sebelum dan sesudah diberikan pendidikan kesehatan mengenai perubahan yang terjadi saat menopause dan pengelolaannya yang dibuktikan dengan terjadinya peningkatan nilai pengetahuan pada hampir semua peserta. Selain itu peserta mengikuti kegiatan pendidikan kesehatan ini sangat antusias mendengarkan materi yang disampaikan oleh pelaksana dan aktif bertanya yang belum dipahami oleh peserta. Ketua RT 41 sangat mengapresiasi kerjasama yang sudah dilakukan pihak pelaksana karena hasil yang didapatkan membuat memahami mengenai cara pengeloaan perubahan tersebut.

\section{KESIMPULAN}

Pemberian informasi kesehatan atau dikenal dengan pendidikan kesehatan yang cukup diharapkan dapat meningkatkan pengetahuan, sikap dan perilaku perempuan, sehingga mereka dapat beradaptasi terhadap perubahan yang terjadi,serta mengatasi masalahnya. Perempuan dewasa akhir yang akan menghadapi masa menopause sudah mempunyai bekal pengetahuan terkait perubahan yang terjadi sehingga nantinya mampu mengelola perubahan yang terjadi. Begitu juga dengan menopause yang sudah mengalami perubahan-perubahan mampu mengelolanya dengan baik sesuai dengan pendidikan kesehatan yang sudah didapatkan melalui ceramah.

\section{REFERENSI}

Astari, R.Y., Tarawan, V.M., Sekarwana, N. 2014. Hubungan Antara Sindrom Menopause Dengan Kualitas Hidup Perempuan Menopause Di Puskesmas
Sukahaji Kabupaten Majalengka. Bul. Penelit. Kesehatan, Vol. 42, No. 3: 171184.

Kundre, R. (n.d.). Pengaruh Penyuluhan Kesehatan Mengenai Menopause Terhadap Tingkat Pengetahuan Ibu Usia 45-55 Tahun Di Wilayah Kerja Puskesmas Tonsea Lama.

Makahanap, M. P., Kundre, R., \& Yolanda, B. (2014). Pengaruh Penyuluhan Kesehatan Mengenai Menopause Terhadap Tingkat Pengetahuan Ibu Usia 45-55 Tahun Di Wilayah Kerja Puskesmas Tonsea Lama. Jurnal Keperawatan, 2(1).

Nursari, Abdul Syukur. (2017).Hubungan Pengetahuan Mengenai Perubahan Fisik Dan Psikis Wanita Klimaterium Terhadap Kecemasan. Kalimantan Timur: Poltekes Kesmenkes.

World Health Organization (WHO). The World Health Organization Quality of life (WHOQOL)-BREF 2 
Jurnal Pengabdian Masyarakat Ners Wiyata

Volume 1 Nomor 1 